\title{
Lebanon's experience in surveillance of communicable diseases during a mass gathering: Sixth Francophone Games, 2009
}

\author{
Nadine Haddad ', Walid Ammar', Alfred Khoury ${ }^{2}$, Alex Cox ${ }^{3}$ and Nada Ghosn ${ }^{1}$
}

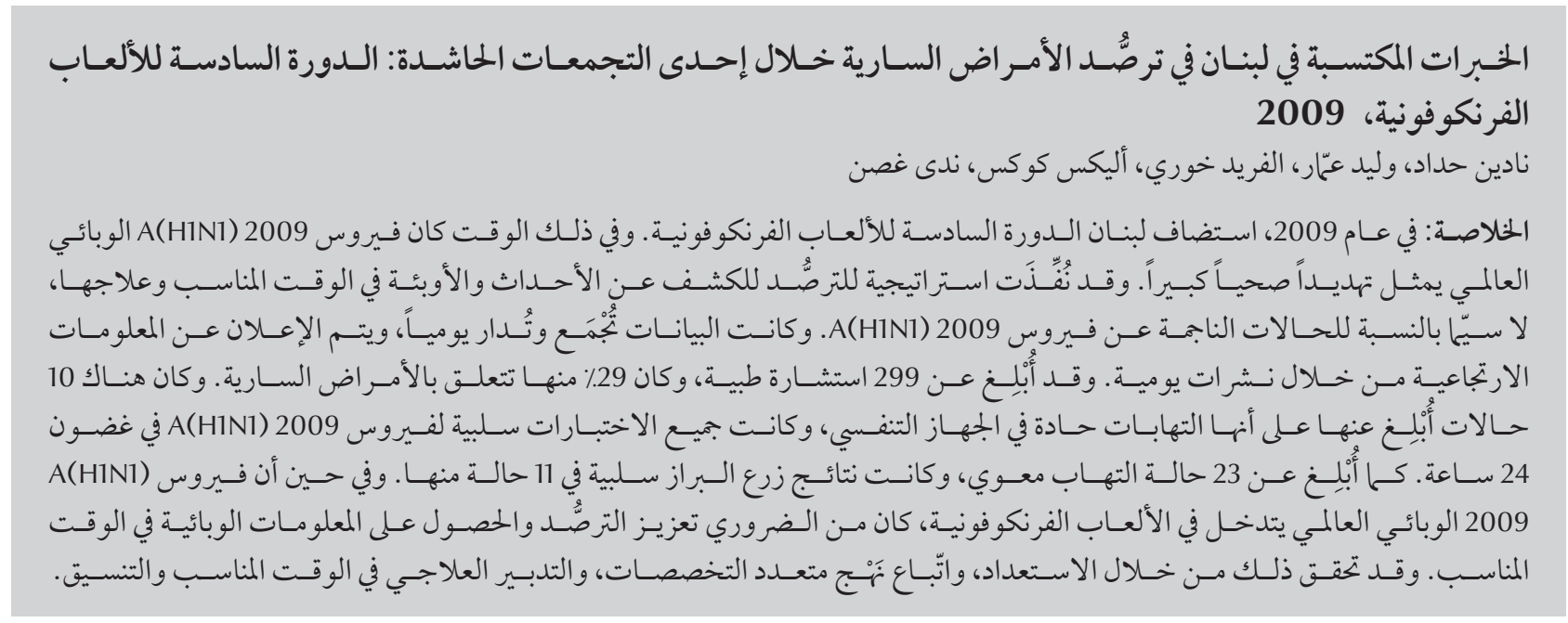

ABSTRACT In 2009, Lebanon hosted the 6th Francophone Games. Pandemic A(H1N1)2009 virus presented significant health threat at the time. A surveillance strategy was implemented for the timely detection and management of epidemiological events and outbreaks, in particular for A(H1N1)2009 virus cases. Data were collected and managed daily and feedback was generated through daily bulletins. A total of 299 medical consultations were reported, $29 \%$ of which related to infectious diseases. There were 10 cases reported as acute respiratory infections; all tested negative for $\mathrm{A}(\mathrm{H1N1}) 2009$ virus within 24 hours. Twenty-three cases of gastroenteritis were reported, for which 11 stool cultures were negative. While pandemic $A(H 1 N 1) 2009$ did not interfere with the Games, it was essential to strengthen surveillance and to have timely epidemiological information. This was achieved through preparedness, a multi-disciplinary approach, timely management and coordination.

Expérience du Liban en matière de surveillance des maladies transmissibles lors d'un rassemblement de masse : sixième édition des Jeux de la Francophonie, 2009

RÉSUMÉ En 2009, le Liban a accueilli la sixième édition des Jeux de la Francophonie. Le virus pandémique A(H1N1) 2009 représentait une menace sanitaire majeure à l'époque. Une stratégie de surveillance a été mise en place en vue d'une détection et d'une prise en charge rapides des événements épidémiologiques et des flambées, notamment de cas de virus $\mathrm{A}(\mathrm{H} 1 \mathrm{N1}$ )2009. Les données ont été collectées et gérées sur une base journalière, et une rétroinformation était générée au moyen de bulletins quotidiens. Un total de 299 consultations médicales a été rapporté, dont 29 \% en rapport avec des maladies infectieuses. Dix cas d'infections respiratoires aiguës ont été notifiés. Tous se sont révélés négatifs au test de recherche du virus $A(H 1 N 1) 2009$ réalisé sous 24h. Vingt-trois cas de gastroentérite ont été signalés, pour lesquels 11 coprocultures se sont révélées négatives. Si la pandémie A(H1N1) 2009 n'a pas impacté les Jeux, il était essentiel de renforcer la surveillance et de mettre en place un système d'information épidémiologique rapide. Ces objectifs ont été atteints au moyen d'une préparation, d'une approche multidisciplinaire, ainsi que d'une prise en charge et d'une coordination rapides.

'Ministry of Public Health, Beirut, Lebanon (Correspondence to: N. Haddad: esu.haddadn@gmail.com). ${ }^{2}$ University Medical Center-Rizk Hospital, Beirut, Lebanon. ${ }^{3}$ European Centre for Disease Control and Prevention, Stockholm, Sweden.

Received: 07/05/15; accepted: 23/05/16 


\section{Introduction}

"Mass gathering" refers to the assembly, whether planned or spontaneous, of a large number of people attending a particular event (artistic, religious, social or sporting) for a certain time period (1). Whether the least number of assembly is defined as 1000 or 25000 $(2,3)$, such events put multiple strains on the host community, particularly in terms of public health implications $(1,4)$. Health risks associated with mass gatherings relate mainly to the increased transmission of communicable diseases, food and waterborne diseases, injuries, environmental threats and bioterrorism $(5,6)$.

Documented experiences show mass gatherings are public health events of international concern, highlighting the need to implement public health and surveillance activities (7-12). Public health plans during mass gatherings rely on several components, such as disease surveillance and outbreak response, environmental and food safety, public health response, mass causality preparedness as well as public information and health promotion $(1,5,6)$.

In 2009, Lebanon hosted the Sixth Francophone Games (6FG) from 27 September to 6 October (13). Approximately 3000 artists and athletes from 46 countries were expected. A "Francophone village" was designated at the Lebanese University Campus in Hadath (Mount Lebanon province) to accommodate all the participants, in addition to their administrative and medical representatives. The risk of increased transmission of communicable diseases was exacerbated in this event given the context at that time of the pandemic influenza A(H1N1)2009 virus (14). The need for epidemiological surveillance during the Games was expressed by the international organizing committee. As a result, close collaboration between the national medical committee of the 6FG and the Lebanese Ministry of Public Health $(\mathrm{MoPH})$ was established during the preparation phase for the event. A surveillance team from the Epidemiological Surveillance Programme (Esumoh) was designated to collaborate with the $6 \mathrm{FG}$ medical committee before and during the Games. An epidemiological surveillance and preparedness plan was developed, specifying needed activities, human resources and partnerships.

The 6FG surveillance plan had 2 main objectives: i) to describe health events occurring during the Games in order to timely detect epidemiological alerts and outbreaks; and ii) to timely detect and manage $\mathrm{A}(\mathrm{H} 1 \mathrm{~N} 1) 2009$ cases in order to mitigate any related risks.

This paper describes the development of the public health and preparedness plan, its implementation before and during the Games and the health events reported during the Games.

\section{Development of the public health and preparedness plan}

\section{Setting}

The temporary Francophone Village included a village clinic that provided free medical consultations to all participants, volunteers and administrative personnel. Participants were also able to seek care from their delegations' medical representatives, when available. The Red Cross was ready at the campus and stadiums to transport patients to nearby hospitals. During the Games, an epidemiological surveillance team, which included 3 epidemiologists, was set up next to the village clinic.

\section{Development of the plan}

As this was the first time Esumoh had conducted mass gathering surveillance, it was essential to review the experiences of other countries while bearing in mind the health threats that acute respiratory infections would pose $(8,15-21)$.
A thorough risk assessment was conducted in order to identify potential health risks. For each participating country, the websites of their health authorities were reviewed in attempt to build their epidemiological profiles. In addition, news websites were screened for reported national or local outbreaks. Diseases were then prioritized according to the likelihood of their occurrence during the 6FG. Priority diseases included acute watery diarrhoea, bloody diarrhoea, acute respiratory infection, non-febrile respiratory syndrome and febrile maculopapular rash (22-32).

The public health and preparedness plan was subsequently developed which included several components: enhancing the national surveillance system, conducting site-specific surveillance, strengthening epidemic intelligence, providing guidelines and training on surveillance and case management, and implementing environmental surveillance.

\section{Implementation of the plan before and during the Games}

\section{Surveillance}

Surveillance during the $6 \mathrm{FG}$ relied on enhancing the national communicable diseases surveillance, as well as conducting site-specific surveillance. Official circulars were issued by the MOPH to hospitals in Beirut and Mount Lebanon, requesting them to immediately report all mandatory notifiable diseases for the 6FG period.

Site-specific surveillance was initiated at the village clinic. Each medical consultation was documented using a standardized medical form, including information on patient identification, disease signs and diagnosis. In addition, the delegations' medical representatives were asked to fill a daily zero reporting form specifying the number of acute respiratory infections, gastroenteritis and 
other febrile diseases. Furthermore, the epidemiological team conducted regular site meetings with the delegations' medical representatives to enhance collaboration.

\section{Guidelines and training}

In an attempt to have a uniform understanding on case definitions and case management (Table 1), specific guidelines were adopted from the national Esumoh surveillance guidelines. The guidelines were incorporated in the 6FG medical booklet, intended for internal use within the village clinic. Prior to the start of the Games, training on site-specific surveillance was conducted for all medical personnel operating at the village clinic as well as the delegations' medical representatives.

\section{Data management}

Medical forms and zero-reporting forms were collected and entered daily in specific databases using EpiData, version 3. Medical diagnoses written on the medical forms were coded using the 10th version of the International Classification of Diseases. Daily analysis was conducted using Excel and compared the relative increase of health events to the previous 3 days.

\section{Epidemic intelligence}

Event-based surveillancewas conducted at the national and supra-national levels. Esumoh epidemiologists performed daily screening of Al-Moktatafat, a daily bulletin that combines all health-related articles published in Lebanese newspapers. In addition, global screening of online sources using MediSys was provided by the European Centre for Disease Prevention and Control.

\section{Environmental surveillance}

Before the 6FG, water samples were taken from the main campus reservoir and several water taps in different locations. Bacteriological results were negative. The campus kitchen was inspected and bacteriological stool cultures were performed for all 15 food handlers. During the event, food specimens were collected daily from every served meal and preserved at $4-8{ }^{\circ} \mathrm{C}$. They were to be tested in case of a foodborne alert. For entomological surveillance, light traps and filter papers soaked with castor oil were placed in the campus fields and the dormitory halls. Their locations were changed every other day, to optimize capturing. In addition, manual mosquito captures were done by volunteers in the campus fields.

\section{Reports and feedback}

A two-page French bulletin summarizing reported cases and alerts was issued daily based on national and site-specific surveillance. Another daily English bulletin, Communicable Diseases Threat Report, for the 6FG was prepared jointly by the European Centre for Disease
Prevention and Control and Esumoh. The bulletins were communicated daily with the 6FG medical committee and delegates, and published on the $\mathrm{MOPH}$ website.

\section{Prevention and control}

At the village clinic, the MOPH provided stockpiles of essential drugs and antiviral medications, in addition to sets for specimen collection and personal protective equipment. Any acute respiratory infection case was considered as suspected $\mathrm{A}(\mathrm{H} 1 \mathrm{~N} 1) 2009$ and was isolated in a dedicated room. $\mathrm{He} /$ she was treated immediately with antivirals while a sample was taken for testing by real-time reverse transcriptase polymerase chain reaction (RT-PCR). Based on the test result, treatment was either continued or suspended. The management of suspected cases was influenced by the experience in Serbia earlier that year (16). Posters in French focusing on hand hygiene, cough etiquette and influenza prevention were distributed throughout the Francophone Village.

\section{Building partnerships}

Several collaborations were essential to carry out these surveillance activities. Expertise and technical support were provided by the World Health Organization (WHO) and the European Centre for Disease Prevention and Control. WHO provided posters and brochures and supported the presence

\begin{tabular}{|c|c|c|c|}
\hline Health event & Case definition & Required specimen & Laboratory tests performed \\
\hline Acute respiratory infection & $\begin{array}{l}\text { Fever }\left(\geq 38^{\circ} \mathrm{C}\right) \text { and one of the } \\
\text { following signs: dry or productive } \\
\text { cough, sore throat, coryza or } \\
\text { sneezing }\end{array}$ & $\begin{array}{l}\text { Nasopharyngeal } \\
\text { swab }\end{array}$ & $\begin{array}{l}\text { Real-time reverse transcriptase } \\
\text { polymerase chain reaction (RT- } \\
\text { PCR) }\end{array}$ \\
\hline Gastroenteritis & $\begin{array}{l}\text { Fever }\left(\geq 38^{\circ} \mathrm{C}\right) \text { and acute bloody or } \\
\text { watery diarrhoea }\end{array}$ & Stool culture & Bacteriological culture \\
\hline $\begin{array}{l}\text { Febrile maculopapular } \\
\text { rash }\end{array}$ & $\begin{array}{l}\text { Fever }\left(\geq 38^{\circ} \mathrm{C}\right) \text { and maculopapular } \\
\text { rash and cough or coryza or } \\
\text { conjunctivitis }\end{array}$ & Oral swab & $\begin{array}{l}\text { Measles and rubella IgM } \\
\text { serology }\end{array}$ \\
\hline
\end{tabular}


of 2 epidemiologists. The European Centre for Disease Prevention and Control provided epidemic intelligence. Measles Immunoglobulin M (IgM) serology, water bacteriological testing and stool bacteriological culture were referred to the clinical laboratory of the Rafic Hariri University Hospital. Timely RT-PCR testing for influenza virus was provided by the research laboratory of the Rafic Hariri University Hospital. Entomological specimens were sent to the Faculty of Arts and Sciences at the American University of Beirut. Food bacteriological testing was undertaken by Fanar Laboratory of the Ministry of Agriculture.

\section{Activities and events during the Games}

\section{Medical consultations}

From 22 September to 7 October 2009, a total of 299 medical consultations were sought at the village clinic. The average daily number of consultations was 18, with a minimum of 3 (on 3 September) and a maximum of 38 (on 26 September). The main reasons for medical consultations on 26 September were headache and superficial injuries.
The largest proportion of medical consultations related to noncommunicable diseases (39\%), followed by trauma and related musculoskeletal conditions (32\%) and infectious diseases (29\%). Among infectious diseases, consultations were for respiratory infection (18\%), watery gastroenteritis (8\%), febrile illness (2\%), bloody gastroenteritis $(0.5 \%)$ and icteric illness (0.5\%) (Figure 1).

\section{Acute respiratory infection}

Twenty-one febrile respiratory infections were reported from the village clinic. Medical delegates reported 7 other febrile respiratory infections. No clustering was observed.

Eight nasopharyngeal swabs were collected from patients with febrile respiratory infection and 2 from patients with febrile syndrome. RT-PCR results were available within $24-48$ hours from specimen collection. All swabs tested negative for A(H1N1)2009.

\section{Acute gastroenteritis}

Twenty-three cases of gastroenteritis were reported from the village clinic and 5 from medical representatives the delegations. Bacteriological culture was performed on 11 stool specimens which all tested negative. On 5 October,
7 cases of watery gastroenteritis were reported which was an increase compared to a maximum of 2 in the previous days.

\section{Daily zero reporting}

A total of 54 zero-reporting forms were received from the medical representatives of 14 delegations between 26 September and 1 October. Reporting completeness was calculated as the number of received forms divided by the number of attending delegations. However, calculating daily completeness was difficult since delegations had different durations of stay. Nevertheless, considering only the 18 delegations that attended the training had medical representatives, the overall completeness rate ranged between 28 and $67 \%$.

\section{Environmental sampling}

Bacteriological tests were negative for all water samples. One food handler tested positive for Salmonella sp. and was consequently excluded from the kitchen before the beginning of the $6 \mathrm{FG}$. Food samples of the meals offered on 30 September were tested and revealed contamination with coliforms although the cause of the contamination was unknown. Entomological surveillance revealed the presence of Aedes cretinus.

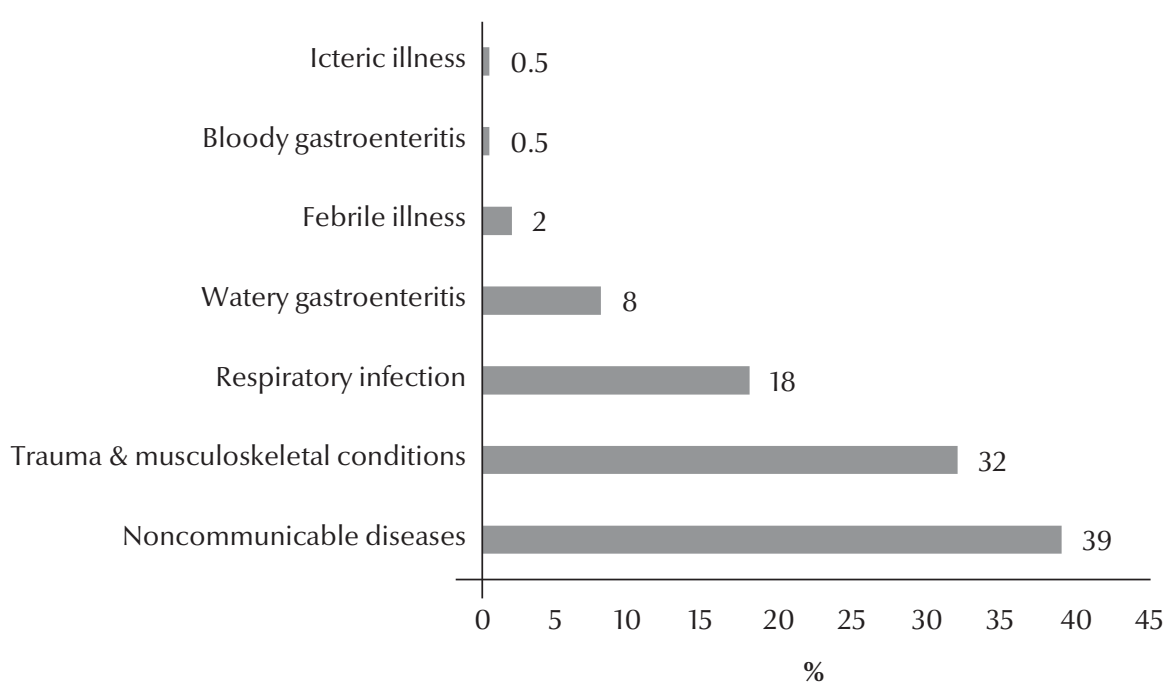

Figure 1 Distribution of clinic consultations by condition during the Sixth Francophone Games, 22 September to 7 October 2009 


\section{Feedback}

Eight daily Communicable Diseases Threat Report bulletins were issued in English, and 7 daily bulletins were issued in French. Information was disseminated daily to all stakeholders and uploaded online on the MOPH website.

\section{Discussion}

Although Lebanon had had previous experience in hosting regional events, the $6 \mathrm{FG}$ was the first mass gathering that integrated epidemiological surveillance activities and represents a valuable learning experience, particularly given in the situation of the pandemic $\mathrm{A}(\mathrm{H} 1 \mathrm{~N} 1) 2009$ virus. Preparation with national and international stakeholders was an essential step for establishing and implementing the public health and preparedness plan.

For the success of the $6 \mathrm{FG}$ public health plan, collaboration functioned between Esumoh MOPH and all stakeholders and contributors at 3 different levels: with the $6 \mathrm{FG}$ medical committee within the Francophone Village, with the ministries involved and the reference laboratories at the national level, and with participating delegations and supranational agencies at the international level.

The main element in the pandemic mitigation plan was the timely detection, confirmation and case management of potential A(H1N1)2009 cases. Close collaboration between Esumoh and the reference laboratory ensured timely testing and feedback. Isolation of suspected cases prior to laboratory confirmation was necessary but inconvenient for athletes. Nevertheless, the mitigation plan was efficient as no increase in acute respiratory infections was recorded.

Trauma and related musculoskeletal conditions accounted for almost one-third of the total medical consultations; this was expected during an event comprising sports competition (6). At the same time, the increase in gastrointestinal cases was also expected as has been reported in the literature $(6,11)$.

The gastroenteritis alert on 5 October was detected one day following onset and coincided with the last day of the 6FG. Delegations were in the process of leaving at the time of detection and therefore the epidemiological investigation was hindered. Only bacteriological stool culture was available and the laboratory results all came back negative.

Food samples were tested following the gastroenteritis alert. However, results were only available 10 days after serving the contaminated meal on 30 September. The main lesson for future events would be to have mechanisms in place to ensure food safety so as to avoid possible foodborne infections, which is more effective approach than detecting contamination once it has occurred.

Zero reporting was an innovative tool in such event-specific surveillance. It was useful for detecting cases seeking care outside the clinic. However, assessing daily or overall completeness was difficult as the denominator varied daily according to length of stay of the delegations. In addition, delegates without medical staff were less compliant. In future similar events, length of stay of delegates should be known in order to adequately monitor completeness.

The presence of Aedes cretinus in environmental samples collected from the Hadath area had already been found in a 2-year mosquito study conducted in Lebanon in 2005 (33). Nevertheless the need to improve the national vector surveillance and control programme is increasing, particularly with the changing climate and ecological conditions that favour vector activity (34).

\section{Conclusion}

Mass gatherings present a unique epidemiological situation where the increased risk of communicable disease transmission can have national and international health implications. Mass gatherings and their associated risks are nowadays regarded as an emerging topic in global health and global epidemiology (12).

The 6FG was the first experience for Lebanon of implementing mass gathering surveillance. Although the size of this assembly was smaller compared to other documented regional mass gatherings, it enriches the literature given that most of the publications in the Eastern Mediterranean region relate to the annual Haj and other religious commemorations (35-39).

Our experience shows that, whatever the type or size of mass gathering, available health infrastructure can be used through careful planning, partnerships and close coordination with various sectors and actors. In order to replicate the 6FG experience in future events to be held in Lebanon, close collaboration between the MOPH and other involved ministries is mandatory.

Moreover, surveillance activities should be continued after the mass gathering event ends. It would be beneficial to designate focal points from each participating country to provide feedback on the health status of their participants after returning to their home country.

\section{Acknowledgements}

We acknowledge the contribution of: Ziad Mansour (WHO Country |Office, Lebanon); Denis Coulombier (European Centre for Diseases Control and Prevention); Jacques Mokhbat (University Medical Center - Rizk Hospital); Pierre Zalouae (Rafik Hariri University Hospital Research Laboratory), Rita Feghali (Rafik Hariri University Hospital, Bacteriology Laboratory); Rima Hage (Ministry of Agriculture, Lebanese Agricultural Research Institute); Khouzama Knio (American University of Beirut, Faculty of Arts and 
Sciences); Ahmad Saleh and Rachelle Louis (Ministry of Public Health, Lebanon).
Funding: Surveillance activities were funded bytheLebanese Ministry ofPublic Health, World Health Organization
Country Office in Beirut and the Sixth Francophone Games Committee.

Competing interests: None declared.

\section{References}

1. Communicable disease alert and response for mass gathering. Key considerations. Geneva: World Health Organization; 2008 (http://www.who.int/csr/Mass_gatherings2.pdf, accessed 17 December 2916).

2. Arbon P, Bridgewater FH, Smith C. Mass gathering medicine: a predictive model for patient presentation and transport rates. Prehosp Disaster Med. 2001;16(3):150-8.

3. DeLorenzo RA. Mass gathering medicine: a review. Prehosp Disaster Med. 1997;12(1):68-72.

4. Public health measures during the influenza $A(H 1 N 1) 2009$ pandemic. Meeting Report. WHO Technical Consultation 26-28 October 2010, Gammarth, Tunisia. Geneva: World Health Organization; 2011.

5. Lombardo JS, Sniegoski CA, Loschen WA, Westercamp $M$, Wade $M$, Dearth $S$, et al. Public health surveillance for mass gatherings. Johns Hopkins Apl Technical Digest. 2008;27(4):347.

6. Mass gatherings and public health: the experience of the Athens 2004 Olympic Games. Copenhagen: World Health Organization Regional Office for Europe; 2007.

7. Severi E, Heinsbroek E, Watson C, Catchpole M, Group HOSW. Infectious disease surveillance for the London 2012 Olympic and Paralymic Games. Euro Surveill. 2012;17(31). pii: 20232.

8. Rossi GP, Sangalli M, Faustini A, Forastiere F, Perucci C. Maladies transmissibles à Rome Lors du Jubilée 2000 [Transmissible Diseases in Rome during the 2000 Jubilee]. Euro Surveill. 2003;8(9).

9. Thackway S, Churches T, Fizzel J, Muscatello D, Armstrong P. Should cities hosting mass gatherings invest in public health surveillance and planning? Reflections from a decade of mass gatherings in Sydney, Australia. BMC Public Health. 2009 Sep 8;9:324.

10. Khan K, Memish Z, Chabbra A, Liauw J, Janes D, Sears J, et al. Global public health implications of a mass gathering in Mec$\mathrm{ca}$, Saudi Arabia during the midst of an influenza pandemic. J Travel Med. 2010;17(2):75-81.

11. Landry P, Slama S. Pèlerinages et grands rassemblements: épidémiologie et prévention [Pilgimage and other mass gatherings: epidemiology and prevention]. Rev Med Suisse. 2004;4:1192-5.

12. Global mass gatherings: implications and opportunities for global health security. Report by the Secretariat. Sixty-fifth World Health Assembly. Provisional agenda item 13.8, 16 March 2012 (A65/18).

13. Organisation Internationale de la Francophonie. 6e Edition des Jeux de la Francophone, 27 septembre-6 octobre 2009, Beyrouth, Liban (http://www.francophonie.org/6e-editiondes-Jeux-de-la.html, accessed 17 December 2016).

14. World Health Organization. Statement to the press by $\mathrm{Dr}$ Margaret Chan, Director-General of the World Health Organization, 11 June 2009 [webpage] (http://www.who.int/ mediacentre/news/statements/2009/h1n1_pandemic_ phase6_20090611/en/, accessed 17 December 2016].

15. Jorm L, Thackway S, Churches T, Hills M. Watching the Games: Public Health Surveillance for the Sydney 2000 Olympic Games. J Epidemiol Community Health. 2003;57:102-8.
16. Loncarevic G, Payne L, Kon P, Petrovic V, Dimitrijveic D, Knezevic $\mathrm{T}$, et al. Public health preparedness for two mass gathering events in the context of pandemic influenza (H1N1) 2009 - Serbia, July 2009. Euro Surveill. 2009 Aug 6;14(31). pii: 19296.

17. Kreidl P, Buxbaum P, Santos-O'Connor F, Payne L, Strauss R, Hrabcik H, et al. European Football Championship - ECDC Epidemic Intelligence Support. Euro Surveill. 2008;13(7-9).

18. The games of the XVIII Olympiad Tokyo 1964. The Official Report of the Organizing Committee. Tokyo: Organizing Committee for the Games of the XVIII Olympiad; 1964 (http:// library.la84.org/6oic/OfficialReports/1964/or1964v1.pdf, accessed 17 December 2016).

19. Rashid H, Haworth E, Shafi S, Memish ZA, Booy R. Pandemic influenza: mass gatherings and mass infection. Lancet Infect Dis. 2008;8(9):526-7.

20. Franco-Paredes C, del Río C, Carrasco P, Santos Preciado Jl. Respuesta en México al actual brote de Influenza AH1N1 [Response in Mexico to the current outbreak of AH1N1 influenza]. Salud Publica Mex. 2009;51(3):183-6.

21. Epidemiological Consultation Team. Surveillance system in place for the 2006 Winter Olympic Games, Torino, Italy, 2006. Euro Surveill. 2006;11(2):E060209.4.

22. Surveillance: cases by month, 11 April 2009 [webpage] (http:// moph.gov.lb/userfiles/files/Esu_data/Esu_pastyears/Lebanon2009.htm, accessed 21 December 2016).

23. Reda R. Typhoid cases in Egypt reach 164. Masress. Published in the Daily News Egypt, 2 July 2009 [website] (http://www. masress.com/en/dailynews/114819? ModPagespeed=noscri pt, accessed 17 December 2016).

24. Irin. Grappling with renewed cholera outbreak, Hanoi, 29 April 2008 [webpage]. (http://www.irinnews.org/report/77970/ vietnam-grappling-with-renewed-cholera-outbreak, accessed 17 December 2016.

25. Irin. Health officials fight cholera outbreak, Bujumbura, 30 July [webpage] (http://www.irinnews.org/report/85505/ burundi-health-officials-fight-cholera-outbreak, accessed 17 December 2016).

26. Irin. 130 cholera cases reported in the Pool region, Brazzaville, 8 May 2009 [webpage] (http://www.irinnews.org/ report/84283/roc-130-cholera-cases-reported-in-the-poolregion, accessed 17 December 2016).

27. Relief Web. Cameroon: Measles; 2009 [webpage]. (http:// reliefweb.int/disaster/ep-2009-000021-cmr-0, accessed 21 December 2016).

28. Wallace E. Measles outbreak in Switzerland: update. Ellenworldnews, 6 February 2009 [website] (http://genevalunch. com/2009/02/06/measles-outbreak-in-switzerland-update, accessed 21 December 2016).

29. Republic of Lebanon: Ministry of Public Health. Communicable Diseases Surveillance, 2009. [webpage] (http:// moph.gov.lb/userfiles/files/Esu_data/Esu_pastyears/Lebanon2009.htm, accessed 21 December 2016).

30. Irin. Instability deprives people of clean water. Guinea-Bissau, 31 March 2009. [webpage] (http://www.irinnews.org/report/83723/guinea-bissau-instability-deprives-people-ofclean-water, accessed 21 December 2015). 
31. Irin. Grappling with renewed cholera outbreak. Vietnam 29 April 2008 [webpage]. (http://www.irinnews.org/report/77970/vietnam-grappling-with-renewed-cholera-outbreak, accessed 21 December 2015).

32. European Centre for Disease Prevention and Control. ECDC Daily Update. Pandemic (H1N1) 2009. Update 06 October 2009 (http://ecdc.europa.eu/en/healthtopics/documents/091006_influenza_ah1n1_situation_report_0900hrs. pdf, accessed 21 December 2015.

33. Knio K, Markarian N, Kassis A, Nuwayri-Salti N. A two-year survey on mosquitoes of Lebanon. Parasite. 2005;12:229-35.

34. Report on the first intercountry meeting of national vector control focal points Amman, Jordan 4-6 November 2008. Cairo: World Health Organization Regional Office for the Eastern Mediterranean; 2009. (http://applications.emro. who.int/docs/who_em_vbc_104_e_en.pdf?ua=1, accessed 17 December 2016).
35. Al-Lami F, Al-Fatlawi A, Bloland P, Nawwar A, Jetheer A, Hantoosh $\mathrm{H}$, et al. Pattern of morbidity and mortality in Karbala hospitals during Ashura mass gathering at Karbala, Iraq, 2010. East Mediterr Health J. 2013;19 Suppl. 2:S13-8.

36. Youbi M, Dghoughi N, Akrim M, Essolbi A, Barkia A, Azami A, et al. Preparedness and health risks associated with Moulay Abdellah Amghar Moussem, Morocco, 2009-2010. East Mediterr Health J. 2013;19 Suppl. 2:S19-23.

37. Hassan S, Imtiaz R, Ikram N, Baig M, Safdar R, Salman M, et al. Public health surveillance at a mass gathering: Urs of Baba Farid, Pakpattan District, Punjab, Pakistan, December 2010. East Mediterr Health J. 2013;19 Suppl. 2:S24-8.

38. Abdullah S, Sharkas G, Sabri N, Iblan I, Abdallat M, Jriesat S, et al. Mass Gathering in Aqaba, Jordan, during Eid Al Adha, 2010. East Mediterr Health J. 2013;19 Suppl. 2:S29-33.

39. Alnsour M, Fleischauer A. Public health considerations for mass gatherings in the Middle East and North Africa (MENA) Region. East Mediterr Health J. 2013;19 Suppl. 2:S42-7. 